\title{
Chapter 5 \\ Saving Humanity from Hell: International \\ Criminal Law and Permanent Crisis
}

\author{
Edwin Bikundo
}

\begin{abstract}
This chapter compares and contrasts temporary international criminal tribunals to the permanent International Criminal Court (ICC) referencing international criminal law's and UN Security Council's (UNSC) relationship to 'crisis'. All the situations where the UNSC has acted in international criminal justice are critical in the sense that they involve crucial decisions where members elect among distinct choices in inherently unstable situations. My argument is that crises enable a negative grounding of legal and political jurisdiction that relies on legitimation that is confirmed by judicial bodies. The analysis outlines the institutionalisation of an exceptional legal mechanism in the practice of the International Criminal Tribunal for the former Yugoslavia (ICTY), its proliferation to the International Criminal Tribunal for Rwanda (ICTR) and its normalisation in the International Criminal Court (ICC). The purpose of this analysis is neither to parse what the law is and what it should be-nor what the law does versus what it promises-, but rather to show how and why individual criminal responsibility in the absence of State intervention demonstrates a globalising political power that is conjoined to a universalising legal glory. A crisis is a liminal situation, which by its ambiguity enables that process of power being linked to glory.
\end{abstract}

Keywords Ad Hoc international criminal tribunals - Chapter VII UN charter • Crisis • International criminal court • International criminal law • United Nations security council

The author is a Lecturer at the Griffith Law School, Griffith University at the Gold Coast in Australia.

E. Bikundo $(\square)$

Griffith Law School, Griffith University, Gold Coast, Australia

e-mail: e.bikundo@griffith.edu.au 


\section{Contents}

5.1 Between Utopia and Dystopia ....................................................................... 90

5.2 International Criminal Law: A Discipline of and for Crisis ................................... 92

5.3 Getting to and from 'twas never thus' to 'twas ever thus' ....................................... 97

5.4 UNSC as a Force Arresting Catastrophe .................................................................. 101

5.5 Conclusion: Real Versus Official Crises .......................................................... 107

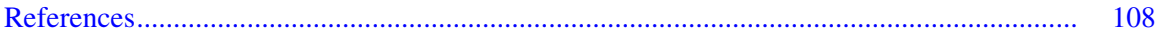

The UN was not created to take mankind to heaven, but to save humanity from hell. ${ }^{1}$

\subsection{Between Utopia and Dystopia}

Crises abound in international criminal law. The ravages of the Second World War (WWII) brought forth the temporary International Military Tribunal at Nuremberg (IMT) and the International Military Tribunal for the Far East at Tokyo (IMTFE). The break-up of the former Yugoslavia necessitated the creation of the temporary International Criminal Tribunal for the former Yugoslavia (ICTY). Civil war in Rwanda brought the temporary International Criminal Tribunal for Rwanda (ICTR) in its wake. Suffice to say that each of these crises, to mention but a few, were exemplary in providing the basis for creating and extending (once novel and temporary but now increasingly commonplace and permanent) international criminal jurisdiction.

To demonstrate how crisis grounds legal and political jurisdiction it is necessary to link the UN Security Council's (UNSC) role in international criminal law to liberal democratic values, such as the rule of law. Along with this, it is required to show how those values have been extended into international criminal law through crisis. In times of crisis the gravity of situation is such that decisive action is called for and yet the correct solution does not suggest itself. In a crisis anything is possible and necessity is the most prevalent justification. A paradigmatic instance of such a crisis and the necessity-driven responses was the end of the WWII and the dilemma of how to deal with the Axis powers' war criminals.

Broadly speaking, the IMT and IMTFE prosecutions exemplified the legalisation of politics, punishing as they did what previously was a political act outside the realm of law. ${ }^{2}$ Gerry Simpson relates how Winston Churchill for the UK initially contemplated summary execution, where Josef Stalin of the Soviet Union

\footnotetext{
1 Dag Hammarskjöld, United Nations Secretary-General from 1953 to 1961, quoted in Weiss 2011 , at 2.

2 Simpson 2007, at 97.
} 
favoured show trials with no possibility of acquittals. ${ }^{3}$ Franklin Roosevelt for the USA, however, came to the view that the best way to deal with the situation was through fair trials affording due process guarantees. Antonio Cassese retells this as in principle a mainstay of democracy. ${ }^{4}$ Carl Schmitt referred to such as inaugurating a global legal order of liberal democratic international justice. ${ }^{5}$ Indeed, as Victoria Sentas and Jessica Whyte note, for liberal democracy the 'law remains a fundamental source of legitimation of a crisis prone system'. ${ }^{6}$ In other words, the crisis of armed conflict enabled the extension of the liberal democratic idea of the rule of law into international affairs through international criminal law. The spectacle of a criminal trial then is more than just the trial and punishment of criminals but also the foundation for a global liberal political order.

As a result of this triumph of the liberal democratic approach to crisis in international criminal law it is this chapter's argument (gradually expounded below) that crisis in international criminal law provides a negative grounding for legal and political jurisdiction where, because nothing is ruled out, all things are possible and anything necessary is permissible simply by not or no longer being forbidden. ${ }^{7}$ Given the UNSC's unique law-making and law-derogating role, the law, while remaining in force, is of no real significance with the key exception of its use as a mechanism for generating legitimacy that founds legality. ${ }^{8}$ Political power and its own justification are not only ultimately unbridled but the exigencies of a given critical situation even ground negatively the legality of the decisions taken. Crisis, moreover, as will be shown following can only be temporally and geographically limited in a local context but not in a global one. Taken separately therefore the temporary international criminal tribunals are all individually limited to specific local contexts but when viewed as a whole in their totality they evince a global phenomenon. It will be argued below that in crisis ultimately it is political effectiveness that seems to be able to provide legitimacy. The political effect produced thereby positively founds both jurisdiction and legality. However, if it were only simply a matter of efficacious conduct why then is the law necessary? This chapter proposes that the law is nevertheless necessary because liberal democratic political power absolutely needs the glory of judicial acclamation for its own legitimacy as a matter of the rule of law. Political power exercised outside of or contrary to law even if effective is inglorious and thus lacks the necessary qualities to found the consensus that liberalism requires. Institutional legitimacy and efficacy as well as relationships between necessity and contingency are resolved through judicial affirmation as legal glorification of political actions that

\footnotetext{
3 Ibid., at 112.

${ }^{4}$ Cassese and Gaeta 2013, at 256.

5 Schmitt 2011, at 39.

${ }^{6}$ Sentas and Whyte 2009, at 9.

7 S.S. Lotus (France v Turkey), PCIJ, 7 September 1927, at 18.

8 Agamben 1998, at 36.
} 
have no positive grounding other than in their own effects. This is because crisis itself cannot be a positive ground but can only be used as negative justification.

The argument proceeds through three stages. First, the argument is made that international criminal law as a discipline was historically both born of crisis and specifically designed to meet crisis. Ordinarily, crises as overwhelming emergent situations are antithetical to laws, which are the product of time and reflection. Examining international criminal law invites us to reflect on what happens when quick action is required wherever there is seemingly little time for reflection. Moreover, whenever rules are laid down in response to crisis then such rules gradually become permanent and institutionalised responses to crisis. This leads to the second point that in practice there is a discernible shift through which what were once exceptional mechanisms gradually become so frequent and familiar as to be rendered indistinguishable from normal ones. This is true in regard not just to the International Criminal Tribunal for the former Yugoslavia (ICTY), the International Criminal Tribunal for Rwanda (ICTR) and the International Criminal Court (ICC) but also in relation to, for instance, the examples of the Special Court for Sierra Leone (SCSL), the Extraordinary Criminal Chambers for Cambodia (ECCC), and the Special Tribunal for Lebanon (STL).

Third, the role of the UNSC in justifying and developing international criminal justice is absolutely ambivalent in that the UNSC rhetorically and practically navigates to avoid both utopian promises and dystopian futures. This is because it is implicitly charged with arresting catastrophe in a chaotic world with the potential for oscillating towards either utopia or dystopia. Indeed, a momentary perfect balance between utopia and dystopia becomes virtually indistinguishable from either of them when viewed through the constraining keyhole of crisis. By employing its primary power to declare official crises, the UNSC tends to focus more on immediate ones that seem to require an element of force or coercion as opposed to real slow-motion on-going accompaniments to crises such as environmental degradation, trade injustices, war profiteering and the like. Liberal democracy in the form that is now global in its reach is and always will be in crisis because it constantly redirects its subject's gaze from the unsatisfactory present toward a future of unfulfilled possibilities. ${ }^{9}$ International criminal law helps to harness this oscillation without end in the name of crisis as if acts done in response to crisis have something other than their own effectiveness as justification.

\subsection{International Criminal Law: A Discipline of and for Crisis}

Crisis, as far as the UNSC with international criminal law invokes it, is permanent and institutionalised. This is because during crises UNSC referrals invoke Chapter VII of the UN Charter that deals with both actual breaches of international peace

9 O’Donnell 2007. 
and security and potential threats to them. ${ }^{10}$ Already in the first few months of 2013 the UNSC had over a dozen particular crises to deal with all over the globe. ${ }^{11}$ Even though, semantically, a crisis is imagined as immediate, localised and temporary, from the UNSC's perspective there is generally one either actual or potential somewhere on the planet. As we shall see below, entertaining the very idea of the end of conflict and the finality of crisis with the triumph of liberal democracy resonates with the theological notion of an eschatology or end of time. ${ }^{12}$ The UNSC is for better or worse institutionally charged with the primary responsibility to deal with crisis and crises that are permanent. Effectively, therefore, exceptional circumstances are normalised in reality, while at the same time are rhetorically maintained as exceptional.

One permanent paradox of international criminal law as a subset of international law that is brought to the fore during crises is that its legitimacy depends upon to what extent it is able to provide for justice, while its effectiveness relies on credible means for its enforcement. As Kofi Annan put it in the context of the Second Gulf War regarding the use of force to gain compliance with international law from Saddam Hussein: 'You can do a lot with diplomacy, but with diplomacy backed up by force you can get a lot more done' ${ }^{13}$ In this sense, the international community has itself set up a system where force is produced to 'solve' problems. ${ }^{14}$ For international law to be effective it has to be conceived of as a set of enforceable rules. That means that international lawyers in their own way essentially minister to this mysterious conjunction of force or might and rules or right in the institution of the UNSC. That is, we are emphatically not revolutionaries, but essentially proselytize the view that the best possible order is coincident with the necessary order. ${ }^{15}$

Dag Hammarskjöld, quoted on the epigraph that opens this study, succinctly anchors the poles of debate examined in the chapter. The wording is expressed in an unmistakably faux-religious idiom. It defers paradise in order to postpone perdition by counselling giving up on utopia in order to escape dystopia. Most importantly, its import is to maintain the purpose of the UN in the perpetual interim, which is based on actual activity rather than any future realisation of an abstract principle. It is pragmatic not messianic, materialist rather than idealist and imagines time as cyclical and not linear. Related to these themes, as we shall see, Hilary Charlesworth's influential paper International Law: A Discipline of Crisis ends on a similar note:

\footnotetext{
101945 Charter of the United Nations, 1 UNTS XVI, Article 39.

11 United Nations, Research Guides and Resources: Security Council Meetings and Actions2013 http://www.un.org/depts/dhl/resguide/scact2013_en.shtml. Accessed 28 October 2013.

12 See Gray's critique of Fukuyama 2006. Gray 2007.

13 Transcript of Press Conference by Secretary-General Kofi Annan at United Nations Headquarters, UN Press Release SG/SM/6470, 24 February 1998. www.un.org/News/Press/ docs/1998/19980224.SGSM6470.html. Accessed 5 March 2013.

14 Charlesworth 2002, at 385.

15 Esposito 2011, at 77.
} 
What if we were to change the type of questions we ask? We could begin from the opposite end and examine what international law has to offer to the person who wants to pollute the environment or violate human rights. I imagine this as an international lawyer's version of C.S. Lewis' Screwtape Letters in which cheery letters from the Devil mock the ease of corrupting humans. ${ }^{16}$

That passage evokes at the very least the historically ambivalent role of lawyers who have not only set about limiting the use of power, but have concurrently facilitated, enabled, justified and maintained its use ${ }^{17}$ What would Mephistopheles make of international criminal law other than reading its foundational texts with an ironic inflection? Giorgio Agamben accuses lawyers for their complicit silence about the killing machine inherently tied to law that he refers to as the state of exception. ${ }^{18}$ In their defence, some lawyers have not been silent but indeed have raised their voice in court. ${ }^{19}$ Agamben, in turn, is accused of making a dangerous move away from understanding law in its context as an epistemic practice of practical reasoning to a kind of ontological or metaphysical presentation of law. ${ }^{20}$

All that notwithstanding, this chapter takes the methodological approach of looking for historical 'signatures' of concepts in Agamben's sense of the term in the practice of the UNSC. These 'signatures' will be taken as indicating where a latter-day concept refers back to that concept's presence in and persistent reference to a separate sphere of thought. ${ }^{21}$ In the present instance, the fields sharing a history of ideas are politics, law and religion. Examples include the temporary loanwords to law from the religious lexicon, such as Hammarskjöld and Charlesworth's words above, to sharing words, such as guilt between law and religion, immunity between biology and law, the notion of 'body' between law, politics, religion and biology. This chapter only focuses on a religious signature regarding the very words and ideas used in and structuring crucial legal and political contexts. This signature has been identified and outlined as affecting not merely vocabulary, idiom and grammar but most importantly also conceptual structure, the foundational efficacy of paradoxes, and generally accepted understandings of time as duration. It is hoped that in the end this effort will open up possibilities to alternative ways of thinking about the fundamental conceptual structures of international criminal law as well as provide food for new thoughts, such as re-focussing international law on issues of structural justice and 'an international law of every day life' that needs a methodology to consider non-elite perspectives. ${ }^{22}$ This exploration includes analysing international criminal justice interventions from the point of view of the people at the business end of

\footnotetext{
16 Charlesworth 2002, at 392.

17 Koskenniemi 2009, at 17.

18 Agamben 2005a, at opening epigraph.

19 Schotel 2009.

20 Ibid.

21 Agamben 2009, at 40.

22 Charlesworth 2002, at 390.
} 
international criminal law. Those on whose behalf such intervention purportedly takes place at times have radically different appreciations of the relevant historical arc and its legal and political ramifications.

Martti Koskenniemi states that historical narrative as a style of legal writing liberates the political imagination to move more freely in the world of alternative choices while illuminating its false necessities and false contingencies. ${ }^{23}$ Although legal vocabulary can seem deceptively open ended, legal practice is often quite predictable. ${ }^{24}$ This gap between vocabulary and practice can be explained when global politics is brought to the equation. For instance, as Charlesworth observes, the legality of the NATO intervention in the then Federal Republic of Yugoslavia (FRY) was unsuccessfully brought before the International Court of Justice by the then FRY in April 1999. ${ }^{25}$ Carla del Ponte, the then ICTY Prosecutor, considered, but ultimately dismissed, prosecutions of NATO actors over the bombing. ${ }^{26}$ Even so, Milosevic was indicted in May 1999 by the ICTY for war crimes, surrendered to that Tribunal by the Serbian government and died during trial. ${ }^{27}$ Antonio Cassese, justified the intervention in terms that the international rule of law should be 'sacrificed on the altar of human compassion' ${ }^{28}$ In general, the discursive structure of international law is for making arguments and not for arriving at conclusions. ${ }^{29}$ It is necessarily contingent because a legal pronouncement would not be certain unless and until it is competently and officially delivered. The point is that even though good legal arguments could be made for either side in both cases the side that carried the day was the more politically powerful one.

International lawyers are preoccupied with great crises, rather than with the politics of everyday life. ${ }^{30}$ Charlesworth's argument is that when international law rhetorically focuses on crises it is static, unproductive and severely restricts what are considered 'fundamental' questions and enquiries. ${ }^{31}$ Crises divert attention from structural issues of global justice. ${ }^{32}$ One aspect of this restricted approach can be seen in that the 'facts' international lawyers deal with are typically outside of their own expertise and the legal discipline does not encourage weighing up

${ }^{23}$ Koskenniemi 2009, at 18.

24 Ibid., at 9.

25 Case Concerning the Legality of the Use of Force (Yugoslavia v United States et al.) ICJ, Request for the Indication of Provisional Measures, Order of 2 June 1999.

${ }^{26}$ International Criminal Tribunal for former Yugoslavia, Final Report to the Prosecutor by the Committee established to Review the NATO Bombing; Campaign against the Federal Republic of Yugoslavia, para 90, http://www.icty.org/sid/10052. Accessed 28 October 2013.

27 The Prosecutor of the Tribunal Against Slobodan Milosevic and 4 others, Prosecutor, Indictment, Case No. IT-99-37, 22 May 1999, http://www.icty.org/x/cases/slobodan_milosevic/ ind/en/mil-ii990524e.htm. Accessed 28 October 2013. Cited in Charlesworth 2002, at 379.

28 Cassese 1999, at 25.

29 Koskenniemi 2005, at 67.

${ }^{30}$ Charlesworth 2002, at 389.

31 Ibid., at 377.

32 Ibid., at 382. 
competing versions of events. ${ }^{33}$ For instance, the perspective of the third world is not as prominent as it could be. The greatest political stakes in this legal debate are whether a new generation of third world scholars can combine legal professionalism with strategic awareness of the limits and possibilities of international law. ${ }^{34}$ As Charlesworth notes, Third World Approaches to International Law (TWAIL) rarely if ever provide alternatives to what they critique. ${ }^{35}$ From a TWAIL perspective, the historically Christian euro-centricism of international law is not so much a criticism as a trite observation. However, its very triteness conceals the on-going sway and profound power of that unique legacy. Moreover, introducing, say, Confucian or even African ideas while in principle not precluded is exceedingly rare in practice. ${ }^{36}$ Such scholars in any case will have to reckon though with a ready-made constricting idiom and structural bias in international institutions. ${ }^{37}$

As part of the idiomatic structure, numerous international law texts employ case studies of crises as a counterweight to the formalism of the study of rules. ${ }^{38}$ The reliance on these case studies actually illustrates that UNSC action itself greatly influences the perception of what the law actually is. ${ }^{39}$ Often in UNSC practice internal legal coherence and consistency are pitted and lose against existential problems of peace and war. ${ }^{40} \mathrm{~A}$ case in point is the requirement under Article 27(3) of UN Charter regarding concurrent vote of permanent members, which is not really observed anymore, as abstention is not counted as a veto. ${ }^{41}$ Given this legally unclear state of affairs, judicial authority carries with it the weighty expressive function of law where a law can have effect even outside of its direct enforcement. $^{42}$ In international criminal law the UNSC's creation of ad hoc international criminal tribunals as well as its referrals to the ICC under Chapter VII of the UN charter are as excellent an example of the use of crises as can be found. The courts and tribunals themselves have at best solely expressed and affirmed a negatively grounded jurisdiction only by finding as a matter of strict legality that nothing prohibits its exercise. ${ }^{43}$ Yet, these judicial pronouncements in effect only affirm the power of the political institution that created the court itself and thus enables the court's initial acceptance of jurisdiction and subsequent provision of

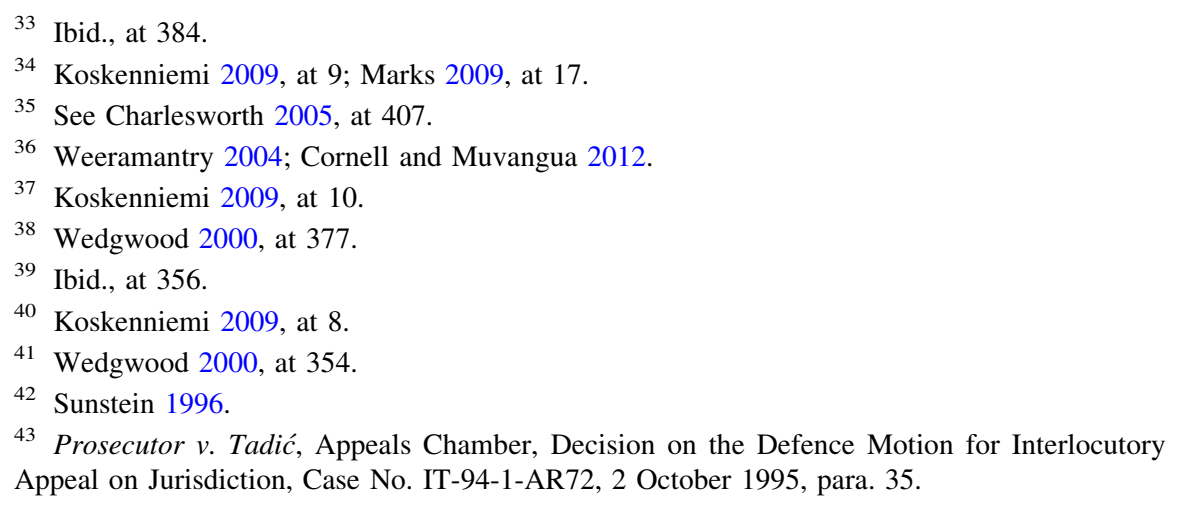


legality. This judicial affirmation approving a political action that founds jurisdiction is subsequently referred to as evidence of a legally and politically efficacious decision. The legal decision demonstrably acts as an acclamation that provides glorification of an already effected political action. That legal glory is therefore only a reflection of an existing political power but that self-same power is considered not fully efficacious (because it is not yet legitimised) until it is glorified. Power thus refers to glory and glory reflects back the power. That is why the law matters to politics or, to put it another way, why power needs glory. ${ }^{44}$ How does this legal machine that utilises false contingency and false necessity to generate glory operate?

\subsection{Getting to and from 'twas never thus' to 'twas ever thus'}

A major flaw of utilising crisis as a model to understand international criminal law is the repetitive rediscovery of an issue as if for the first time. Therefore analyses have little to no reference to past knowledge or present conventions. ${ }^{45}$ That is, every set of circumstances constituting a crisis is taken to be unique-literally without precedent even when followed subsequently by similar iterations of the same mechanism. Moreover, as can be seen in the proliferation of international criminal tribunals, as explained below, those so-called exceptions frequently become the new rule. ${ }^{46}$ The legal basis for establishing international tribunals and furnishing such with criminal jurisdiction is a case in point.

The legal basis for establishing the ICTY was written up only after the political decision to set it up had been made. In the UN Secretary-General's report that led to the establishment of the ICTY, he noted that treaty-based bodies were the normal way of setting up judicial bodies that would exercise international jurisdiction over individuals criminally responsible for violating international humanitarian law. ${ }^{47}$ Such a method allowed not only for detailed and comprehensive discussion of issues regarding establishment but also enabled the full exercise of sovereign will. However, the usual way of doing things would not do in the particular situation because of the considerable amount of time it would take to debate, draft, sign and ratify such an instrument and the fact that its coming into force would by no means be a given. Such was the urgency of the situation that it even precluded the UN General Assembly's participation. The exceptional procedure of a Chapter VII resolution setting up a tribunal was favoured for reasons of

\footnotetext{
44 Agamben 2011a, at 195.

45 Charlesworth 2002, at 384.

46 Koskenniemi 2009, at 10.

47 UNSC, Report of the Secretary General pursuant to Paragraph 2 of Security Council Resolution 808 (1993), S/25704, 3 May 1993, paras. 18-30.
} 
immediacy and efficiency, and justified in the particular circumstances of the former Yugoslavia. ${ }^{48}$ To go the treaty route was described as too cumbersome and uncertain for the circumstances at hand. The report noted that discussions at the General Assembly and within the International Law Commission canvassing a permanent court that would have universal jurisdiction were already in the offing. A UNSC resolution under Chapter VII then was expeditious to meet this particular set of events. It was therefore intended not to legislate new law but only to provide a new mechanism for the enforcement of established law: an unprecedented tribunal applying existing law. Despite the language repeatedly emphasising the particular nature of the Yugoslavian crisis, the report noted that setting up a tribunal was itself legally justifiable both by being consistent with previous UNSC practice and as an enforcement measure under Chapter VII. This would as such provide it with the extraordinary effect of being immediately effective and accompanied by a binding obligation over all States to do whatever was necessary to achieve its aims.

The legal basis for establishing the ICTR only took four paragraphs to outline, whereas it had taken thirteen in the case of the ICTY. ${ }^{49}$ The case of Rwanda followed a similar pattern to the case of the former Yugoslavia in referencing exceptional circumstances particular to it. Even if the model of setting up the ICTR drew from the experience of and closely followed the ICTY in practice, it would appear from the relevant report of the UN Secretary-General (UNSG) as if the ICTY was not for that reason to be considered a wholly adequate legal precedent. This was because Rwanda was still considered on its own particular merits the ICTY notwithstanding. ${ }^{50} \mathrm{~A}$ significant difference was that Rwanda itself fully participated in the ICTR's establishment and so its sovereignty was not in question. Subsequent judicial decisions and state practice do appear to confirm in principle the legality of the establishment of such ad hoc tribunals by the UNSC. ${ }^{51}$

The ICC then came along and was established in a hybrid form as can be seen in Article 13 of the Rome Statute. ${ }^{52}$ The court may exercise jurisdiction if a State Party refers a situation to the Prosecutor, if the UNSC acts under Chapter VII of the UN Charter, or if the Prosecutor initiates an investigation on his (or now her) own motion. It is therefore not only a treaty-based body following the recognisedas-normal form and process but it also institutionalises the exceptional power first seen and developed with the ad hoc tribunals created by UNSC resolutions under the UN Charter. This exceptional power has now been normalised in the Rome Statute and enshrined in treaty law. Furthermore, under Article 10, matters of

\footnotetext{
48 UNSC Res. 808/1993, 22 February 1993.

49 UNSC, Report of the Secretary-General pursuant to Paragraph 5 of UNSC Res 955 (1994), S/1995/134, 13 February 1995, paras. 6-9; UNSC, Report of the Secretary General pursuant to Paragraph 2 of UNSC Res 808 (1993), S/25704, 3 May 1993, paras. 18-30.

50 UNSC, Report of the Secretary-General pursuant to Paragraph 5 of UNSC Res 955 (1994), S/1995/134, 13 February 1995, paras. 6-9.

51 Cassese 2008, at 327; Zahar and Sluiter 2008, at 9.

522002 Rome Statute of the International Criminal Court, 2187 UNTS 3, Article 83(2).
} 
jurisdiction, admissibility and applicable law do not affect existing international law nor do they create new law outside of the Statute. Effectively, that provision insulates the core portions of the Rome Statute from being invoked as authoritative on either customary or general international law. ${ }^{53}$ This in effect means that both treaty and UNSC powers to create tribunals are concurrently inside and outside the Statute. They are, to borrow a phrase from Equity, like two streams in a river whose waters do not mix, as the cases of ad hoc tribunals set up after the ICC for Lebanon, Cambodia and Sierra Leone also attest. George Fletcher and David Ohlin consequently view the ICC as two courts, an independent criminal court enacted by parties to the Rome Statute and in the case of referrals by the Security Council under Article 13(b) of the Statute, an organ for restoring collective peace and security transcending the classic goals of criminal law to adjudicate individual guilt'. ${ }^{54}$ Therefore, depending 'on how a case is generated, then, the ICC can be either an independent criminal court, prosecuting international criminality for its own sake, or a UN body prosecuting criminals as an instrument to advance the Council's security objectives'. ${ }^{55}$

By the time setting up the STL came round, a single paragraph sufficed to provide and explain its legal basis: ${ }^{56}$ that legal basis is a treaty between the United Nations and Lebanon. ${ }^{57}$ The STL is a sui generis entity being neither a subsidiary organ of the United Nations, nor part of the Lebanese judiciary. ${ }^{58}$ In defining the legal basis the UN Secretary-General reviewed UN practice over 13 years past, which revealed three different types of founding instruments for international or internationally assisted tribunals. They were established by Security Council resolution, national statute or by agreement between the United Nations and the country directly interested in the creation of the tribunal. ${ }^{59}$

Bruno Simma acknowledges that in so called 'hard cases' or for our purposes in crisis situations political imperatives and morally based arguments dictate actions outside the law. ${ }^{60}$ The UNSC Chapter VII power is inexhaustible. It uses crises as a state of exception in order to simultaneously suspend and fulfil the law. ${ }^{61}$ Even when courts examine this power it is only confirmed in the double negative

53 Schabas 2010, at 267.

54 Fletcher and Ohlin 2006, at 427.

55 Ibid.

56 UNSC, Report of the Secretary-General on the Establishment of a Special Tribunal for Lebanon, S/2006/893, 15 November 2006.

57 Ibid.

58 Ibid.

59 UNSC, Report of the Secretary-General pursuant to Paragraph 6 of resolution 1644 (2005), S/ 2006/176, 21 March 2006.

${ }^{60}$ Simma 1999, at 22. Cited in Charlesworth 2002, at 381.

61 Agamben 2005b, at 106. 
(the UNSC does not not have this power to found tribunals). The suppleness of crisis is such that not even Chapter VII exhausts its fecundity in creating precedents in fact that are not precedents in law. This extract from the UK House of Lords debating the resort to force in Iraq before the Second Gulf War makes the points discussed above clear. It is grounded on a false necessity for war and relies upon decisions to be taken in light of circumstances at the time (not previously laid down rules). Further to that, all options are left open (nothing is ruled outmeaning therefore force is ruled in), while the Kosovo campaign is cited for support but emphatically not as precedent:

Lord Bach: What I have mentioned today are, I repeat, prudent preparations: first, to put up a credible threat of force against Saddam Hussein, but also in case war is necessary which is something that is neither imminent nor inevitable. It would be the Government's preference that there should be a second resolution, if that is necessary, before any force was used. But I have to tell the noble Lord that any decision on further action by the Security Council will be taken in the light of the circumstances at the time and that all options are open.

It is important to state that it is up the Security Council to uphold its authority and to take whatever action is necessary to ensure full compliance. Historical parallels can be dangerous, but it is perhaps worth noting that the Kosovo campaign was not one that was supported by the Security Council. I think that very few Members of this House would say that that was not a campaign that deserved to succeed or that it was not in the interests of humanity. ${ }^{62}$

The NATO bombing campaign in the FRY reinforced the idea that collective security and the international order, at the end of the day, are based on the threat of the use of force. ${ }^{63}$ This flight from law makes violence seem if not intuitive then inevitable. International lawyers interpret intervention as in itself almost automatically active and productive, while non-intervention is inactive and negative. ${ }^{64}$ The only possible courses of action in the face of a crisis are to act or not to act. In this way international law steers clear of analysis of longer-term trends and structural problems. ${ }^{65}$ Robin Cook, the then British Foreign Secretary, compared the intervention in Kosovo to the fall of the Berlin wall in 1989 marking the end of another crisis, the Cold War. ${ }^{66}$ In his view, the Kosovo intervention appeared to violate international law because it begun without taking the matter to the UNSC under Chapter VII of the United Nations Charter. However, the United Kingdom together with the United States argued that it was consistent with the humanitarian values of the Charter and that armed intervention in another state to protect human rights was acceptable in international law regardless of national sovereignty. ${ }^{67}$

\footnotetext{
62 United Kingdom Parliament House of Lords Daily Hansard, www.publications.parliament.uk/ pa/ld200203/ldhansrd/vo021218/text/21218-09.htm. Accessed 28 October 2013.

${ }^{63}$ Charlesworth 2002, at 390.

${ }^{64}$ Ibid., at 387.

65 Ibid., at 389.

66 Ibid., at 379 .

${ }^{67}$ Ibid., at $378-379$.
} 
Here crisis enabled sovereignty, a key principle of international law to be trumped by humanitarian principles.

Opposed to this position, Simon Chesterman and Michael Byers pointed out that the NATO bombing was a regression by centuries to when military force was the default tool of powerful states and the less powerful sought protection in alliances rather than liberal democratic multilateral institutions or international law. ${ }^{68}$ Similarly, the report of the Independent International Commission on Kosovo concluded that the NATO intervention breached international law because it was not authorised by the UN Security Council, still, it was morally and politically legitimate as a response to serious human rights violations. ${ }^{69}$ These legal arguments did not carry the day in the face of NATO opposition. International relations scholars appear less exercised taking a position on the NATO campaign, perhaps because it is more easily interpreted in the paradigm of power politics than in the international lawyers' world of objective legal principles that are justified by reference to the rule of law. ${ }^{70}$

\subsection{UNSC as a Force Arresting Catastrophe}

The essential connection between the UNSC's power to regulate international violence and its ability to set up criminal tribunals was first judicially confirmed in the Prosecutor $v$ Tadic case in $1995 .{ }^{71}$ This nexus subsequently found its way into the Rome Statute. As mentioned earlier, Article 13 of the Rome Statute codifies three separate modes for exercising jurisdiction. A referral by the UNSC, however, is conceptually a very different proposition in that the power therein flows from UNSC action that was not explicitly provided for in the UN Charter. As explained above, in the Tadic case the ICTY affirmed the legality of its own establishment by the UNSC. ${ }^{72}$ That court said that 'neither the text nor the spirit of the [United Nations] Charter conceives of the UNSC as legibus solutus (unbound by law)'. Yet, the court essentially recognised a power of the UNSC that did not proceed from anything more than the acts of the UNSC itself. However, as the court pointed out, because that power was not limitless or subject to no review, the power had to comply with the conditions of its exercise which in this case were the restoration and maintenance of international peace and security. The inherent

\footnotetext{
68 Chesterman and Byers, 1999. Cited in Charlesworth 2002, at 380.

69 Independent International Commission on Kosovo 2000, at 288-289; House of Commons Foreign Affairs Select Committee, Fourth Report, 23 May 2000, www.parliament.the-stationeryoffice.co.uk/pa/cm199900/cmselect/cmfaff/28/2802.htm. Accessed 28/10/2013 Both cited in Charlesworth 2002, at 380-81.

70 Charlesworth 2002, at 381.

71 Prosecutor v. Tadić, Appeals Chamber, Decision on the Defence Motion for Interlocutory Appeal on Jurisdiction, Case No. IT-94-1-AR72, 2 October 1995, paras. 26-28.

72 Ibid.
} 
jurisdiction of the court to decide was described as inversely proportional to the textual discretion of the UNSC to act. In other words, the UNSC could act to give jurisdiction to the ICTY only insofar as doing so was not inconsistent with the Council's mandate. Further, the court clarified that the Charter conceived of the Council as having specific powers (not absolute fiat), which could not exceed those of the UN itself in its jurisdiction and its internal divisions of power.

The power of the UNSC to invoke Chapter VII powers to initiate or stop an investigation by the ICC as enshrined in Articles 13 and 16 of the Rome Statute thus historically originated from UNSC Resolution 808 of 1993 as affirmed by the ICTY. José Alvarez unfavourably compares the decision of the STL's Appellate Chambers in the case of Ayyash and others, to the ICTY's Tadic judgment. In the Ayyash case, as it was in the Tadic case, the defence fundamentally challenged the jurisdiction and legality of the Tribunal. It, however, met with different results at the appellate stage where that Tribunal found that it did not have the power to engage in 'judicial review' over the UNSC. ${ }^{73}$ Alvarez criticises this STL Appeal Chamber's finding as affirming that the UNSC is unbound by law. ${ }^{74}$ The thing to note, though, is that regardless of the opposed finding the effect of both Tadic and Ayyash is that the UNSC gets its way and that the accused is subject to trial. In terms of legal glorification the opposed findings by the STL and ICTY reveal that judicial pronouncements notwithstanding, the effectiveness of political actions remains.

It is interesting that when the ICTY needed to explain and justify the then novel idea that the UNSC could indeed create an international tribunal, it reached for the obscure phrase to state that the Security Council is a creature of law, not a lawless entity. Thanos Zartaloudis traced how the expression 'legibus solutus' was transferred from imperial Rome to medieval ecclesiastical authorities and even onward to the notion of 'the people' as a politically legitimising entity. ${ }^{75}$ Kenneth Pennington, in turn, provided four different but related meanings for legibus solutus. ${ }^{76}$ First is the prince's authority to change, derogate, or dispense from positive law. Second is the prince's immunity from prosecution. Third is the prince's authority to transgress or dispense from the normal rules governing the legal system. Fourth is the prince's power to transgress the rights of the subject.

This taxonomy seems to indicate that the ICTY in Tadic only referenced the third meaning regarding the transgression of or dispensation from the normal rules governing the legal system. So the ICTY were saying the UNSC was not legibus solutus in the sense that it did not have the authority to transgress the system's normal legal rules even though it left unsaid that the UNSC was legibus solutus in

\footnotetext{
73 Ayyash and others, Appeals Chamber, Decision on the Defence Appeals Against the Trial Chamber's 'Decision on the Defence Challenges to the Jurisdiction and Legality of the Tribunal', Case No STL-11-O1/PT/AC/AR90.1, 24 October 2012, paras. 32-50.

74 Alvarez 2013, at 301.

75 Zartaloudis 2010.

76 Pennington 1993, at 90-91.
} 
at least the first sense by not being explicitly excluded from setting up novel international criminal tribunals and therefore able to do so. The UN Charter along with the Nuremberg and the Far East trials brought forth the international community as a legal concept that placed the leaders of all human communities under the rule of international law. ${ }^{77}$ Therefore, in their wake any authority should theoretically never be above the law in the sense of acting completely outside of and with no reference to the law. The point is that the UNSC is not absolved of legal obligations. ${ }^{78}$ Setting up criminal tribunals is part of its power, even though that is in tension with its primarily police functions. ${ }^{79}$ This is the only legally defensible position because a legal system is the weaving of legal rules to legally regulated institutions, leaving no power in the state or in society that is de legibus solutus. ${ }^{80}$ That is, all powers are subject to the legal authority of other powers and nobody is supposed to be above or beyond the rules. How can the rules address imminent or actual crises or catastrophes when these by their nature seem to resist the application of ordinary rules or regimes of law? How do we extend the rule of law to cover crisis through international criminal law?

Hammarskjöld's crucial words quoted above were not only expressed in a Christian idiom but sit squarely within a framework with Christian antecedents. Secularisation is intrinsic to Christianity. ${ }^{81}$ As the religion of secularisation, it is "no longer, but still, religion'. ${ }^{82}$ The Peace of Augsburg in 1555 inaugurated the modern European settlement between politics and religion that was reinforced and augmented with the Westphalian Peace of $1648 .{ }^{83}$ It is easy to forget Westphalia's secularised religious power turning the earlier logic in its head. Instead of religious leaders choosing temporal rulers, temporal rulers chose the religion for their realms. The notion that now political rulers could choose the faith of their realms, and not religious leaders choosing political leaders, cuius regio, eius religio, led to 'a Christian and Universal Peace'. ${ }^{84}$ Modern politics was rendered possible because it acquired formerly religious power. Even while liberal politics disarticulates religious authority de facto, if not de jure, liberal peace is derivative of as well as parodies a transcendent sovereignty. ${ }^{85}$ Thus imperial theology feeds 'on the remnants of eschatological history and their abandoned meanings' ${ }^{86}$ Speaking with reference to these abandoned meanings George Steiner stated that when belief in neither Heaven nor Hell exists, Hell nevertheless proves easier to recreate, thus there is currently an

\footnotetext{
7 Tomuschat 2006, at 830 .

8 Gill 1995, at 48.

9 Simma et al. 2012, at 1320.

80 O'Donnell 2004, at 37.

81 Esposito 2011, at 60.

82 Ibid., at 71.

83 Fletcher 2004, at 59.

84 Wright 1961, at 21.

85 Fletcher 2004, at 59.

86 Hell 2009, at 311.
} 
extinct theology at work, whose death has produced its parody where 'the concentration and death camps of the twentieth century are Hell made immanent ${ }^{97}$ This hell is directly resonant with Hammarskjöld's quote at the beginning of this piece as well as with the atrocities that gave rise to international criminal law.

According to Agamben there is more at stake here than meets the eye because every power that thinks of itself as destined to block or delay catastrophe may be considered a secularisation of the 'Katechon' ${ }^{88}$ The Katechon is a biblical idea of something restraining hell, while perpetually postponing heaven. This is specifically from 2 Thessalonians 2:6-7 where Paul states in an eschatological context that Christians must not behave as if the apocalypse would happen tomorrow, since the revelation of the Antichrist is conditional upon the removal of something or someone that restrains him-that restraint being the Katechon. The Katechon therefore prevents the eschatological crisis of the end of the world but by so doing also prevents the apocalypse where Christ reveals himself.

According to Paul Fletcher, imperial political theology utilises the metaphysics of crisis and, given its necessary temporality, its mood is unequivocally imperative. ${ }^{89}$ Chapter VII resolutions are in the imperative mood, which is to say in the form of a commandment. For further understanding the rhetoric used by the UNSC, Aristotle's classification can be relied on. He classified rhetoric in three ways: political, which looks to the future and is hortatory; law that looks at the past in making judgments; and ceremony focuses on the present. ${ }^{90}$ In a somewhat different manner, Giorgio Agamben traces two ontologies relevant to this discussion. First is the assertion, which is in the indicative mood and second is the commandment in the imperative mood. One refers to 'is', the other to 'be'. One belongs to science and philosophy, the other to politics, law, religion and magic. ${ }^{91}$ The UNSC is definitely political in its rhetoric and in that regard brings into being legal jurisdiction merely by the power of pronunciation.

Martti Koskenniemi notes in passing the ambivalence of the Katechon, while coincidentally at the same time identifying Carl Schmitt as the most acerbic critic of liberal universal humanitarianism. ${ }^{92}$ Schmitt utilises this idea of what or who restrains to describe the contemporary as caught between the in-between times. Just as UNSC actions are. ${ }^{93}$ Schmitt then recasts history as a long interim and not a long march toward some imagined goal. ${ }^{94}$ For Agamben, the Katechon defers the end of days from becoming concrete. ${ }^{95}$ This neutralises the very idea of salvation

87 Steiner 1971, at 54.

88 Agamben 2005b, at 110 .

89 Fletcher 2004, at 59.

90 Aristotle 1984, at 32.

91 Agamben 2011c, from 14:10.

92 Koskenniemi 2007, at 422-423.

93 Schmitt 2003, at 59-60.

94 Schmitt 2008.

95 Agamben 2011b, at 7-8. 
in history of any sort (including through international criminal law). As per Agamben with specific application to international criminal law, Walter Benjamin's definition of guilt as an originally juridical concept that was transferred to the religious sphere supports Schmitt's thesis that the concept of guilt is not an essence but an operation. ${ }^{96}$ For Benjamin, law is a residue of demonic existence, while Schmitt asserts that the basis of guilt is not the freedom of the ethical human but only the controlling force of a sovereign power that only slows the Antichrist. ${ }^{97}$ For Schmitt therefore the notion of guilt, which is central to international criminal law, is linked to the Katechon and refers to an operation of law rather than an intrinsic objective quality. It is the result of an official act rather than the status of any real being.

According to Charlesworth a crisis allows us to factor out ambiguities and complex contexts in the area of collective security. ${ }^{98}$ This by default "means that little attention is paid to the role that non-state actors, such as multinational corporations, and the international monetary institutions play in generating insecurity'. ${ }^{99}$ That reinforces 'the idea that collective security and the international order, at the end of the day, are based on the threat of the use of force'. ${ }^{100}$ For Paolo Virno, the ambivalence of the Katechon is accompanied by oscillation and makes up cultural apocalypses such as we see conjured up to justify actions undertaken in response to crisis. ${ }^{101}$ Roberto Esposito expounds further on this ambivalence of the Katechon as the positive of a negative: the Katechon restrains evil by holding it within itself, confronts evil from within by hosting it, defers evil but does not eradicate it because eradicating evil would be to eliminate itself. ${ }^{102}$ It delays the explosion of evil at the price of preventing the victory of good. ${ }^{103}$ The constitutive juridical principle of the Katechon opposes the absence of law by taking it up inside itself and giving it form, rule and norm. ${ }^{104}$ It nurtures and is nurtured by iniquity, opposing by preserving and confronting by incorporating. ${ }^{105}$ It fulfils the law not through obedient action but in the form of potential action. ${ }^{106}$ The Katechon imposes the norm on both messianic and satanic anomie. ${ }^{107}$ It can be any institution that guarantees order such as any State, or the Church or even be the

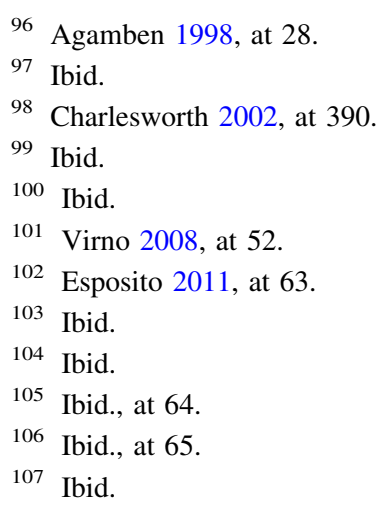


point of intersection between politics and law and religion. ${ }^{108}$ It is expressible as a structural analogy and may even function as a religious legitimation of power. The sovereign State, which the UNSC imitates, now and then 'needs a sacred core around which to establish its legitimacy in a way that goes beyond its historical origin and prolongs its life over time.' ${ }^{109}$ The UNSC reprises the Katechon function in that they are both made immortal by the infinite mortality of sacrificed subjects under their jurisdiction. ${ }^{110}$ The UNSC plays the role of Katechon during crisis to restrain total breakdown, and crisis itself is actually or potentially (which is really the same thing) permanent.

Virno is of the view that because the Katechon impedes the coming of the Antichrist, yet this coming is a condition for the redemption promised by the Messiah, then the Katechon also impedes the redemption. ${ }^{11}$ Institutionally, the Katechon adapts itself best to the permanent state of exception in the boundary between legal and factual questions. ${ }^{112}$ The ambivalence of the infinite regress by which questions of fact can always be seen in questions of law and vice versa is restrained (but not removed) by the Katechon. ${ }^{113}$ Virno notes the ambivalence of critical situations where loss offers the only possibility of redemption, where crisis offers no remedy apart for what the danger itself describes and prescribes. ${ }^{114}$ Culturally, apocalypse is the ritualistic accompaniment of the state of exception where crisis implies the suspension of ordinary law. ${ }^{115}$ This provides an environment where a normative proposition is simultaneously an instrument of control and a phenomenon to be controlled, the unit of measurement and the reality to be measured. ${ }^{116}$ Virno further locates the Katechon in verbal language as 'the maximum source of danger' as well as 'the authentic arresting force'. ${ }^{117}$ Language therefore has a dual structure especially in the context of constructing the apocalypse where the crisis is also a renewal for humanity. ${ }^{118}$ Language brings forth the danger and is also the force that restrains it. ${ }^{119}$

Who could be a more exemplary Katechon than the referee of the football match that took place between the SS and inmates during a break from work at Auschwitz? ${ }^{120}$ Presumably despite the sheer horror of the camp, he was

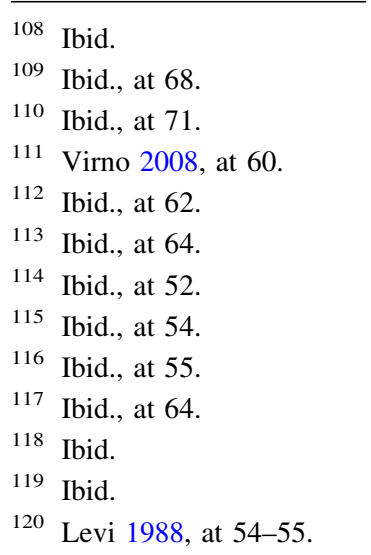


scrupulously fair in ensuring the ball did not go out of bounds nor was played by hand, and was equally ready to issue red and yellow cards to either side. Is the referee like Faust or like Mephistopheles? Agamben says that this moment of normalcy is the true horror of the camp and if we do not succeed in understanding and stopping the match then all hope is lost. ${ }^{121}$ The match is never over but continues regardless of time and place. ${ }^{122}$ Therefore, while seemingly neutral, ambivalent and ambiguous the Katechon is on balance necessarily tolerant of evil and is therefore to be resisted.

\subsection{Conclusion: Real Versus Official Crises}

On the back of the preceding discussion we can make at least three provisional conclusions to help us drive to a final conclusion. First, international criminal law is both made in and made for crisis; second, it is designed to address brief moments in time that are in reality of perpetual continuation, and third, the UNSC has the central role in responding to crisis by ambivalently restraining catastrophe. Setting up tribunals itself or setting in motion the machinery of international criminal justice such as the ICC is one of the tools at its disposal. Essentially, the UNSC administers the international order through, among others, international criminal justice. Even the relatively independent treaty-based ICC is coupled to the UNSC by the referral and deferral powers of the UNSC under Articles 13 and 16 respectively of the Rome Statue. International justice depends as much on matters of administration as on questions of law. ${ }^{123}$ This administrative managerial approach is mostly about actor's interests, so the formal aspects of legality such as hard and fast rules are viewed unfavourably as obstacles. ${ }^{124}$ The task at hand for many lawyers, according to Koskenniemi, remains 'how to smooth the prince's path'. ${ }^{125}$ According to him, this approach conceals a normativity privileging values and actors occupying dominant positions in international institutions without any critical stance. ${ }^{126}$ The notion of management of crisis is therefore key and the law is only a handmaiden to this. In Agamben's terms, we should focus more on the police and less on law, less on sovereignty and more on government. $^{127}$

\footnotetext{
121 Agamben 2000, at 26.

122 Ibid.

123 Fletcher and Ohlin 2006, at 427.

124 Koskenniemi 2009, at 15.

125 Ibid., at 16 .

126 Ibid.

127 Agamben 2011b, at 276.
} 
By focusing on how the response to crisis is governed and administered we can see through the analysis above that it is only by the UNSC considering a particular situation as critical that it becomes officially so. Not as a matter of essence but one of operation. This separates the subject of the action from the action itself. In international criminal law crisis is not an essence but an operation likewise and by extension guilt is not an essence but an operation. The action is effective regardless of the morality of the actor or the factual basis of the situation. ${ }^{128}$ The efficacy of official UNSC actions under crisis is indifferent to its morality because morality is not what effects its actions. Only its official status as being primarily responsible for keeping the peace brings efficacy to its acts. Moral principles are consequently only reached for to provide rhetorical legitimation.

\section{References}

Agamben G (1998) Homo Sacer: sovereign power and bare life. Stanford University Press, Stanford

Agamben G (2000) Remnants of Auschwitz: the witness and the archive. Zone Books, New York Agamben G (2005a) State of exception. University of Chicago Press, Chicago

Agamben G (2005b) The time that remains: a commentary on the letter to the Romans. Stanford University Press, Stanford

Agamben G (2009) The signature of all things: on method. Zone Books, New York

Agamben G (2011a) The sacrament of language: an archaeology of the oath. Stanford University Press, Stanford

Agamben G (2011b) The kingdom and the glory: for a theological genealogy of economy and government. Stanford University Press, Stanford

Agamben G (2011c) The archaeology of commandment. www.egs.edu/faculty/giorgio-agamben/ videos/the-archaeology-of-commandment/. Accessed 31 March 2013

Agamben G (2013) Opus Dei: an archaeology of duty. Stanford University Press, Stanford

Alvarez JE (2013) Tadić revisited: the Ayyash decision of the Special Tribunal for Lebanon. J Int Crim Justice 11:291-302

Aristotle (1984) The rhetoric and the poetics of Aristotle. Modern Library, New York

Cassese A (1999) Ex iniuria ius oritur: are we moving towards international legitimation of forcible countermeasures in the world community? Eur J Int Law 10:25-30

Cassese A (2008) International criminal law, 2nd edn. Oxford University Press, Oxford

Cassese A, Gaeta P (2013) Cassese's international criminal law, 3rd edn. Oxford University Press, Oxford

Charlesworth H (2002) International law: a discipline of crisis. Mod Law Rev 65:377-392

Charlesworth H (2005) Current trends in international legal theory. In: Blay SKN, Piotrowicz RW, Tsamenyi BM (eds) Public international law: an Australian perspective, 2nd edn. Oxford University Press, South Melbourne, pp 402-411

Chesterman S, Byers M (1999) Has US power destroyed the UN? London Review of Books 21:29-30

Cornell D, Muvangua N (2012) Ubuntu and the law: African ideals and post-apartheid jurisprudence. Fordham University Press, New York

Esposito R (2011) Immunitas: the protection and negation of life. Polity, Cambridge

Fletcher GP, Ohlin JD (2006) The ICC—-two courts in one? J Int Crim Justice 4:428-433

128 Agamben 2013, at 40. 
Fletcher P (2004) The political thelogy of the empire to come. Camb Rev Int Affairs 17:49-61

Fukuyama F (2006) The end of history and the last man. Free Press, New York

Gill TD (1995) Legal and some political limitations on the power of the UN Security Council to exercise its enforcement powers under chapter VII of the Charter. Neth Yearb Int Law 26:33-138

Gray J (2007) Black mass: apocalyptic religion and the death of utopia. Farrar Straus and Giroux, New York

Hell J (2009) Katechon: Carl Schmitt's imperial theology and the ruins of the future. Germanic Rev Literature Culture Theory 84:283-326

Independent International Commission on Kosovo (2000) The Kosovo report: conflict, international response, lessons learned. Oxford University Press, Oxford

Koskenniemi M (2005) From apology to utopia: the structure of international legal argument. Cambridge University Press, New York

Koskenniemi M (2007) The gentle civilizer of nations: the rise and fall of international law 1870-1960. Cambridge University Press, Cambridge

Koskenniemi M (2009) The politics of international law, 20 Years Later. Eur J Int Law 20:7-19

Levi P (1988) The drowned and the saved. Summit Books, New York

Marks S (2009) False contingency. Curr Leg Problems 62:1-21

O'Donnell G (2004) The quality of democracy: why the rule of law matters. J Democracy 15:32-46

O'Donnell G (2007) The perpetual crises of democracy. J Democracy 18:5-11

Pennington K (1993) The prince and the law 1200-1600: sovereignty and rights in the Western legal tradition. University of California Press, Berkeley

Schabas W (2010) The International Criminal Court: a commentary on the Rome Statute. Oxford University Press, Oxford

Schmitt C (2003) The nomos of the Earth in the international law of the jus publicum Europaeum. Telos Press, New York

Schmitt C (2008) Political theology II: the myth of closure of any political theology. Polity Press, Cambridge

Schmitt C (2011) Writings on war. Polity Press, Cambridge

Schotel B (2009) Reviews: defending our legal practices: a legal critique of Giorgio Agamben's state of exception. Amsterdam Law Forum. http://ojs.ubvu.vu.nl/alf/article/view/68/124. Accessed 31 March 2013

Sentas V, Whyte J (2009) Law, crisis, revolution: an introduction. Aust Feminist Law J 31:3-14

Simma B (1999) NATO, the UN and the use of force: legal aspects. Eur J Int Law 10:1-22

Simma B, Khan D-E, Nolte G, Paulus A (2012) The Charter of the United Nations: a commentary, 3rd edn. Oxford University Press, Oxford

Simpson G (2007) Law, war and crime: war crimes trials and the reinvention of international law. Polity Press, Cambridge

Steiner G (1971) In Bluebeard's Castle: some notes towards the redefinition of culture. Yale University Press, New Haven

Sunstein CR (1996) On the expressive function of law. Univ Pens Law Rev 144:2021-2053

Tomuschat C (2006) The legacy of Nuremberg. J Int Crim Justice 4:830-844

Virno P (2008) Multitude: between innovation and negation. Semiotext(e), Los Angeles

Wedgwood R (2000) Unilateral action in the UN system. Eur J Int Law 11:349-359

Weeramantry CG (2004) Universalising international law. Martinus Nijhoff Publishers, Leiden

Weiss TG (2011) Thinking about global governance: why people and ideas matter. Routledge, New York

Wright Q (1961) The role of international law in the elimination of war. Manchester University Press, Manchester

Zahar A, Sluiter G (2008) International criminal law: a critical introduction. Oxford University Press, New York

Zartaloudis T (2010) Giorgio Agamben: power, law and the uses of criticism. Routledge, New York 